\title{
Nosocomial meningitis caused by Klebsiella pneumoniae producing carbapenemase, with initial cerebrospinal fluid minimal inflammatory response
}

Meningite nosocomial por Klebsiella pneumoniae produtora de carbapenemase, com resposta inflamatória inicial mínima no líquido cefalorraquidiano

Meningitis caused by $K$. pneumoniae is a common problem following neurosurgery ${ }^{1}$; however, reports of $K$. pneumoniae $\mathrm{KPC}$ producing (KP-KPC) strains isolated from cerebrospinal fluid (CSF) are infrequent ${ }^{2,3}$.

A 47 year-old woman that suffered a series of subarachnoid hemorrhages underwent microembolization of an aneurysm in the anterior communication artery of the brain (April, 2010). On June, she returned with fever and abdominal pain. The tomography showed an abdominal abscess located near the tip of ventricle-peritoneal shunt. CSF characteristics are on Table. Initiated vancomycin (500 mg/6h) and meropenem (1,000 mg/8h).

In the second CSF culture KP-KPC was identified, CSF biochemistry was normal, although minor increase of WBCs $\left(6\right.$ cells $/ \mathrm{mm}^{3}$ ). CSF lactic acid and CSF/serum glucose rates fell within normal ranges; despite both are sensitive and specific biomarkers to differentiate bacterial from nonbacterial meningitis ${ }^{4}$. These conditions may therefore confound or delay correct diagnosis leading to delay in the initiation of antibiotic therapy.

The bacteriological culture of third CSF sample indicated KP-KPC and CSF parameters consistent with bacterial meningitis. This calls attention to the delayed inflammatory response in a case with infection by a bacteria with high mortality rate as KPC in a patient not exhibiting any other form of immunosuppression. This was not reported before. To date, only two studies have been identified reporting the discovery of KP-KPC isolates from $\mathrm{CSF}^{2,3}$, and none of these presented CSF data.

Identification of isolates and determination of their antimicrobial susceptibility were accomplished using the automated VITEK system (bioMerieux, Hazelwood, MO). A polymerase chain reaction $(\mathrm{PCR})^{5}$ was applied to all $K$. pneumoniae isolates to search bla $a_{\mathrm{KPC}}$ genes. PCR products were sequenced and compared with GenBank database sequences (http://www.ncbi.nih.gov/BLAST) identifying $b l a_{\mathrm{KPC}-2}$.

Table. Cerebrospinal fluid cytology and biochemical characteristics.

\begin{tabular}{|c|c|c|c|c|}
\hline & $06 / 18 / 2010$ & $06 / 24 / 2010$ & $06 / 30 / 2010$ & $07 / 14 / 2010$ \\
\hline $\mathrm{RBC} / \mathrm{mm}^{3}$ & 240 & 297 & 5.0 & 4134 \\
\hline $\mathrm{WBC} / \mathrm{mm}^{3}$ & 3.1 & 6.2 & 960 & $1710 *$ \\
\hline Neutrophils \% & ND & 1 & 85 & 94 \\
\hline Lymphocytes \% & ND & 87 & 12 & 6 \\
\hline Monocytes \% & ND & 12 & 3 & 0 \\
\hline Eosinophils \% & ND & 0 & 0 & 0 \\
\hline CSF/blood glucose & 0.78 & 0.88 & 0.13 & 0.35 \\
\hline $\mathrm{TP} \mathrm{mg} / \mathrm{dL}$ & 20 & 12.3 & 252 & $188^{*}$ \\
\hline Lactic Acid mmol/L & 1.5 & 1.1 & 9.2 & 7.1 \\
\hline Gram bacterioscopy & No bacteria & No bacteria & No bacteria & Gram-negative rods \\
\hline Culture & coagulase-negative staphylococci & KP-KPC & $K P-K P C$ & $K P-K P C$ \\
\hline
\end{tabular}

RBC: red blood cell; WBC: White blood cell; KPC: Klebsiella pneumoniae Carbapenemase; ND: not done; TP: total protein. *CSF values corrected with RBC number: WBC $1704 \mathrm{cell} / \mathrm{mm}^{3}$; TP $182 \mathrm{mg} / \mathrm{dL}$.

\footnotetext{
'Laboratório de Bacteriologia, Hospital de Clínicas, Universidade Federal do Paraná, Curitiba PR, Brazil;

${ }^{2}$ Instituto de Pesquisa Pelé Pequeno Príncipe, Curitiba PR, Brazil;

${ }^{3}$ Hospital Universitário, Serviço de Patologia Clínica, Universidade Federal de Santa Catarina, Florianopolis SC, Brazil.

Correspondence: Libera Maria Dalla Costa; Universidade Federal do Paraná; Rua Padre Camargo, 280; 80060-240 Curitiba PR, Brasil; E-mail: Imdc@ufpr.br Conflict of interest: None declared. The Ethical Committee of the Hospital de Clínicas da Universidade Federal do Paraná approved this report.

Received 25 February 2014; Accepted 17 March 2014.
} 
The patient was treated with polymyxin B (500,000 UI $12 \mathrm{~h} / 12 \mathrm{~h}$ ) persisted with fever. KP-KPC was isolated from a fourth CSF culture, additional intrathecal polymyxin B $50,000 \mathrm{UI} / 24 \mathrm{~h}$ (3,000 UI/24h) was initiated. The patient died on July 22, 2010.

The occurrence of bacterial meningitis without or with minimal cellular response early in the course of the infection is rare $^{6}$. Poor meningeal inflammatory response is usually observed in older patients or neonates, alcoholism, AIDSrelated immunosuppression, neoplastic, diabetes mellitus, or corticosteroid therapy. It is usually associated with low white blood cell count ${ }^{6}$.

In the current case study, minimal CSF cell increase was observed, predominately in the form of lymphocytes. However, previous data have indicated that $15 \%$ of culturepositive cases of acute bacterial meningitis presented more than $50 \%$ lymphocytes or mononuclear cells, and this was observed chiefly in neonates and in patients with a total CSF WBC counts below 100 cells $/ \mathrm{mm}^{37}$.

The diagnosis of nosocomial meningitis by KP-KPC must be considered even in cases with mild CSF alterations. Therapeutic options for treatment of infections caused by KPC producing bacteria are extremely limited and reports of clinical outcome remain infrequent. Common treatments based on in vitro susceptibility testing include the polymyxins, tigecycline, and aminoglycoside antibiotics ${ }^{8}$.

\section{Sérgio Monteiro de Almeida, Keite da Silva Nogueira, Jussara Kasuko Palmeiro, Mara Cristina Scheffer, Christiane Johnscher Niebel Stier, João Cesar Beenke França, Libera Maria Dalla Costa}

\section{References}

1. Srinivas D, Veena Kumari HB, Somanna S, Bhagavatula I, Anandappa CB. The incidence of postoperative meningitis in neurosurgery: an institutional experience. Neurol India 2011;59:195-198.

2. Rhomberg PR, Jones RN. Summary trends for the meropenem yearly susceptibility test information collection program: a 10-year experience in the United States (1999-2008). Diagn Microbiol Infect Dis 2009;65:414-426

3. Beirão EM, Furtado JJ, Girardello D, Ferreira Filho D, Gales AC. Clinical and microbiological characterization of KPC-producing Klebsiella pneumoniae infections in Brazil. Braz $J$ Infect Dis 2011;15:69-73.

4. de Almeida SM, Faria FL, de Goes Fontes $\mathrm{K}$, et al. Quantitation of cerebrospinal fluid lactic acid in infectious and non-infectious neurological diseases. Clin Chem Lab Med 2009;47:755-761.

5. Naas T, Cuzon G, Villegas MV, Lartigue MF, Quinn JP, Nordmann P. Genetic structures at the origin of acquisition of the beta-lactamase bla KPC gene. Antimicrob Agents Chemother 2008;52:1257-1263.

6. Geiseler PJ, Nelson KE, Levin S, Reddi KT, Moses VK. Community acquired purulent meningitis: a review of 1316 patients during the antibiotic era 1954-1976. Rev Infec Dis 1980;2:724-745.

7. Powers WJ. Cerebrospinal fluid lymphocytes in acute bacterial meningitis. Am J Med 1985;79:216-220.

8. Hirsch EB, Tam VH. Detection and treatment options for Klebsiella pneumoniae carbapenemases (KPCs): an emerging cause of multidrugresistant infection. J Antimicrob Chemother 2010;65:1119-1125. 